\title{
WNT6 wt Allele
}

National Cancer Institute

\section{Source}

National Cancer Institute. WNT6 wt Allele. NCI Thesaurus. Code C53004.

Human WNT 6 wild-type allele is located in the vicinity of $2 q 35$ and is approximately $14 \mathrm{~kb}$ in length. This allele, which encodes protein wnt-6, plays a role in cellular differentiation. The wild-type allele is expressed at elevated levels in colorectal cancers. 